Health related quality of life (HRQOL) in survivors of lymphoma: A systematic review and methodological critique

\begin{tabular}{|r|l|}
\hline Journal: & Leukemia and Lymphoma \\
\hline Manuscript ID: & GLAL-2009-0694.R1 \\
\hline Manuscript Type: & Review \\
\hline Date Submitted by the \\
Author: & 18-Dec-2009 \\
\hline Complete List of Authors: & $\begin{array}{l}\text { Arden-Close, Emily } \\
\text { Pacey, Allan } \\
\text { Eiser, Christine }\end{array}$ \\
\hline Keywords: & $\begin{array}{l}\text { Lymphoma and Hodgkin disease < Neoplasia, health-related quality } \\
\text { of life, survivorship }\end{array}$ \\
\hline
\end{tabular}

\title{
scholarONE \\ Manuscript Central
}


1

Health related quality of life (HRQoL) in survivors of lymphoma: $\underline{\text { A systematic }}$ review and methodological critique

Running title: Quality of life in lymphoma survivors: review

E Arden-Close ${ }^{1}$, A Pacey $^{2}, \&$ C Eiser ${ }^{1}$

${ }^{1}$ Department of Psychology, University of Sheffield

${ }^{2}$ Academic Unit of Reproductive and Developmental Medicine, School of Medicine and Biomedical Sciences, University of Sheffield

Author for Correspondence: Emily Arden-Close

Address

Department of Psychology

University of Sheffield

Western Bank

Sheffield

S10 2TP

Tel:

00441142226583

E-mail:

e.arden-close@sheffield.ac.uk

Keywords: Lymphoma and Hodgkin Disease, Health-related quality of life, survivorship 


\begin{abstract}
$\underline{\text { ABSTRACT }}$
Survival rates for Hodgkin's Lymphoma and Non-Hodgkin's Lymphoma have improved in recent years. However, these improvements are associated with various late effects, which can compromise health-related quality of life (HRQoL). Improving HRQoL is a significant goal in oncology, and increasingly one of the primary outcomes in clinical trials, but is dependent on availability of reliable and sensitive measures. This review therefore aimed to: (i) identify and evaluate commonly used HRQoL measures; (ii) compare HRQoL in lymphoma patients with the general population; and assess the association between (iii) HRQoL and different treatments; and (iv) HRQoL and demographic, medical and psychological variables. Standardized systematic searches identified 18 eligible studies that included adult survivors of lymphoma and reported quantitative results by histological diagnosis. Information about design, sample, measures and findings was extracted from each study. Survivors of lymphoma experienced worse physical but comparable mental HRQoL to the general population. No conclusions could be drawn about the association between different treatments and HRQoL. Correlates of better HRQoL included younger age, educational level, being employed, male gender, earlier stage disease, not having co-morbid illnesses, and meeting public health exercise guidelines. Limitations of current research relating to research design, sample demographics and reporting of descriptive statistics were identified. Given the increasing numbers of patients living with lymphoma, controlled studies using appropriate measures are required to determine the HRQoL consequences associated with the condition.
\end{abstract}


The lymphomas [Hodgkin's Lymphoma ( $\underline{\mathrm{HL}}$ ) and Non-Hodgkin's Lymphoma (NHL)] are among the most common cancers to affect individuals of all ages although NHL tends to be more common in older people [1]. Survival rates for both cancers have improved rapidly, and current five-year survival rates of $87 \%$ for $\underline{\text { HL }}[2]$ and $65 \%$ for NHL [3] have been reported. However, physical late effects, including cardiac dysfunction, secondary malignancies, neuro-cognitive impairment and gonadal dysfunction have been identified [4]. Such effects may compromise healthrelated quality of life (HRQoL). This is typically defined as a multidimensional concept covering all aspects of well-being, including physical functioning (ability to carry out everyday physical activities), mental functioning (emotional functioning), social functioning (ability to interact in the usual way in society) and role functioning (involvement in life situations related to work, household chores, and family life) [5]. Improving HRQoL is a significant goal in oncology, and increasingly one of the primary outcomes in clinical trials [6].

HRQoL has been assessed in survivors of $\underline{\mathrm{HL}}$ and NHL in a number of studies, but the evidence has not been reviewed systematically. Such a review would facilitate understanding of long-term HRQoL among lymphoma survivors and the extent to which it may be influenced by medical, demographic and psychosocial factors. This information could in turn enable healthcare professionals to provide patients with information about the long-term impact of their disease, suggest ways in which late effects may be prevented or reduced, and provide an indication about who would benefit from counselling.

Any conclusions about HRQoL are necessarily dependent on the quality of measures available. Measures can be evaluated on a number of criteria including: reliability (test-retest reliability and internal consistency), validity, and appropriateness for the population of interest [7]. Reliability is usually indicated by internal consistency or Cronbach's alpha, the extent to which the items of a scale assess the same concept. An internal consistency of 0.70 or above is generally considered to be acceptable [8]. Test-retest reliability is established when individuals complete a measure on two separate occasions and their scores are highly correlated. 
Validity refers to the extent to which the measure reflects the construct of interest. It is generally assessed by comparison with similar measures and correlation with observable criteria. Finally, for this review, measures were considered appropriate for lymphoma survivors if they were either generic (applicable to anyone) or survivorspecific. Measures designed to assess HRQoL during initial treatment, with their emphasis on physical symptoms were not considered sensitive to the issues affecting survivors..

We therefore report a systematic review to determine HRQoL in survivors of HL or NHL. Our first aim was to identify and evaluate commonly used measures. In addition, we aimed to determine (i) HRQoL relative to the general population; (ii) associations between HRQoL and different treatments; and (iv) associations between HRQOL and demographic, medical and psychological variables.

\section{METHOD}

The literature search aimed to identify any research study published in a peer reviewed journal that assessed HRQoL in survivors of lymphoma (HL or NHL) at least six months post treatment, using a standardized measure of HRQoL. Articles were excluded if they: (i) sampled childhood cancer survivors only; (ii) were case reports or reviews of previous literature; or (iii) did not report analyses by histological diagnosis.

Three methods were used to locate relevant studies: a keyword search, a backward search, and a manual search of relevant journals. First, the databases Medline, PsycInfo and Web of Knowledge were searched for articles published in the English language covering the period from January 1985 to April 2009. The search included the following terms: Hodgkin's disease, lymphoma (non-Hodgkins), and health-related quality of life. After each term was entered into the keyword function the cancer-related terms were combined using the OR function. This generated 32 hits from PsycInfo, 157 hits from Medline, and 456 hits from Web of Knowledge. After initial review of the abstracts those that did not meet the inclusion criteria were excluded. This resulted in identification of 36 articles as potentially eligible. Despite extensive searches, one article [9] could not be traced. Following the keyword search, 
we then carried out a backward search in which we located papers by examining the reference lists of all papers obtained from the first step. This identified nine further articles. Then, following a manual search of the journals 'Psycho-Oncology,' 'European Journal of Cancer,' 'Journal of Clinical Oncology' and 'Quality of Life

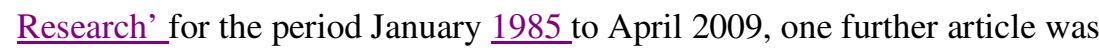
identified. This resulted in a total of 45 articles that were obtained and examined against the inclusion and exclusion criteria.

\section{RESULTS}

\section{Review of the articles}

Following detailed review of the articles against the inclusion/exclusion criteria, 18 articles based on 15 data sets were retained. The following information was extracted from each study: aims, sample size by histological diagnosis (including percentage of men) and response rate, age, time since diagnosis, treatment, comparison group where applicable, measures and results. The studies were conducted in the US $(n=4)$, Norway ( $n=3$ ), the Netherlands ( $n=2)$, Israel, France, Spain, Sweden, Austria and Canada (1 each). All studies included demographic or medical variables as correlates of HRQoL.

\section{Aim 1: Evaluation of Measures}

Five different measures of HRQoL were identified. These are summarized and assessed for reliability, validity and appropriateness for lymphoma survivors in

Table I. We identified eight studies which utilised a generic measure (the SF-36 health survey; [10]) to compare lymphoma survivors to the general population. The remaining measures were disease specific. These included three appropriate for assessment during treatment (EORTC QLQ-C30: [11]; FACT-An: [12]; CARES [Ganz et al., 1992][13]) and one designed for survivors (QoL-CS: [14] - two studies).

\section{Aim 2: HRQoL relative to the general population}

HRQoL was compared with that of the general population in ten articles that covered eight datasets. These articles are summarised in Table II. Eight articles

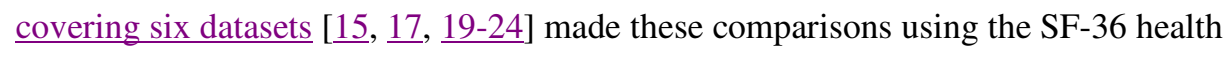


survey [10]. In all eight articles, lymphoma survivors reported worse physical functioning relative to the general population even when controlling for symptoms of post-traumatic stress disorder (PTSD) [15]. Lymphoma survivors also reported worse social functioning relative to the general population [19]. However, the mental component summary (which in the SF-36 includes emotional and social but not

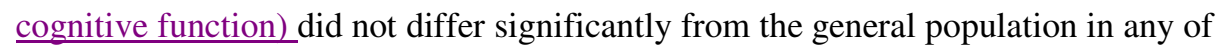
these eight studies, although impaired functioning relative to controls was noted on some subscales $[19,20]$. The mental component summary is more reliable and comprehensive than the subscales it comprises.

Two additional articles $[16,18]$ compared lymphoma survivors with the general population using the EORTC QLQ-C30 (see Table II). Lymphoma survivors reported worse physical functioning than the general population in both studies. In addition, survivors reported worse social functioning, more fatigue, more problems with physical role and cognitive functioning [18], and more dyspnoea (shortness of breath) $[\underline{16,18}]$.

Aim 3: Associations between treatments and HRQOL

Deleted: II

Details about associations between treatments and HRQoL are reported in

Tables II and III. Lymphoma survivors who had been treated by chemotherapy reported worse social well-being (as measured by the CS-QoL) and worse psychological well-being relative to survivors who had not had chemotherapy [22]. They also reported worse social and physical well-being, more fertility concerns, and greater influence of cancer and its treatment on employment relative to those who had had radiotherapy specific to the tumour site [25]. Those who had experienced mantle field radiation either alone or in combination with chemotherapy had more dyspnoea than those who had not [30]. Finally, survivors who had experienced combined modality therapy (chemotherapy plus radiotherapy) reported more deficits in physical functioning, dyspnoea, pain and fatigue than those who had been treated by either chemotherapy or radiotherapy alone [29].

However, the evidence above is based on studies with heterogeneous samples which precluded comparisons between chemotherapy regimens. A cross-sectional comparison of MOPP, ABVD and MOPP/ABVD chemotherapy demonstrated no differences in terms of effects on physical and mental HRQoL [16]. Finally, a 


\section{Demographics}

Although older age was associated with worse physical HRQoL [뜨, $\underline{18-19}$, $\underline{22}, \underline{32}$, worse mental functioning was found for younger patients [29]. Men reported better role functioning [18], fewer role limitations [19] better physical functioning $[16,19]$ and better emotional functioning [19] than women. In contrast, one study found that men experienced greater fatigue and worse overall HRQoL than women [30]. Lower educational level was associated with worse HRQoL [18-19, 21].

Finally, employed survivors reported better physical functioning than unemployed survivors [21,32], as well as better emotional HRQoL and general health [21] and better vitality and mental functioning [22].

Medical variables

More advanced disease was associated with worse HRQoL [24], but those who relapsed did not report worse HRQoL than those who remained disease-free [23]. Better vitality, social functioning, emotional role and mental health were found for those 10-15 years post-diagnosis than those 5-9 years post-diagnosis [20, 22]. In contrast, Greil et al. [29], found no relation between time since treatment and any domains of HRQoL. The presence of co-morbid illnesses was associated with worse physical HRQoL [18, 21-22, 32].

Psychosocial, lifestyle and other variables

More PTSD symptoms were associated with worse mental and physical functioning [15]. A lower sense of coherence (defined as the extent to which individuals believe their life to be comprehensible, meaningful and manageable) [33] was associated with worse HRQoL [24]. Financial problems were associated with worse mental functioning $[24,26]$. Meeting public health guidelines for exercise was associated with better HRQoL in patients with NHL [27, 31]. This was a significant 
dose-response relation, where HRQoL improved as exercise increased [27]. Patients experienced more dyspnoea if they were older, had a lower educational level and a history of medical complications [18]. Finally, sleep disturbance was associated with dyspnoea, fatigue, pain, financial difficulties and worse global HRQoL [30].

\section{DISCUSSION}

In considering the HRQoL of survivors of lymphoma, we recognise first the importance of the specific measure of HRQoL adopted. All measures identified had acceptable reliability and validity (table 1). Three of the measures identified (the EORTC QLQ C-30 [11], the FACT [12] and the CARES [13] might be considered inappropriate for cancer survivors since they capture immediate effects of diagnosis and treatment rather than issues relating to re-integration and late effects [34]. Further, as a cancer-specific measure, the EORTC measure is inappropriate for use by general population controls. Despite this, two studies compared HRQoL between lymphoma patients and the general population using this measure. Thus, the conclusions should be treated with caution.

Most frequently, HRQoL was assessed using the SF-36 [10]. This is a generic measure, and therefore appropriate for comparison with the general population but does not address the specific problems experienced by cancer survivors. The only measure specifically developed for cancer survivors is the QoL-CS [14]. However, several issues have been identified with this measure: although it is intended for survivors longer than five years post diagnosis, validation was based on survivors 428 months post-diagnosis; several items assess distress at the time of diagnosis and treatment; and some items ask about change but fail to indicate direction (meaning that survivors with positive and negative responses would receive the same scores)

[35]. Further, there are no disease-specific modules for survivors, even though some late effects differ as a function of cancer site.

In an attempt to address these issues, it has been recommended that studies should use two measures where possible: a survivor-specific measure to assess quality of life, and a generic measure [36-37]). Attention needs to be given to creating more sensitive measures of quality of life for cancer survivors, so that their problems can be documented and addressed appropriately (see also [38]). 
There is some evidence that HRQoL in the first two years after diagnosis does not differ depending on the specific treatment [28]. However, the participants in this study were younger than the general population with lymphoma. Since many late effects are not apparent until several years after treatment, more long-term follow up studies are required to compare the relative side-effects of different treatment regimens. We found some evidence that chemotherapy is associated with worse social HRQoL relative to other treatments [22,25]. Chemotherapy often leads to fatigue [40], which may account for this finding. However, patients with advanced stage disease are also more likely to be treated with chemotherapy, meaning that the effect of treatment may be confounded by stage [25].

The relation between older age and worse physical HRQoL was expected, and can be explained in several ways. First, older people are more likely to suffer from co-morbid illnesses. Second, some late effects are more likely to occur as time since treatment (and therefore age) increases [4]. Furthermore, physical health tends to decline with age for the general population.

Lower educational level was associated with worse HRQoL in three studies. Lower socioeconomic status has been associated with a less healthy lifestyle in general [41] which may be reflected in poorer HRQoL, probably because those with 
lower educational qualifications are also likely to be lower earners. Such patients are more likely to be employed in manual work, and consequently may have to take more time off work following completion of treatment, leading to constraints in their financial circumstances, which have been associated with worse mental health [25]. In support of this idea, unemployment was associated with worse physical HRQoL [21].

Survivors who reported meeting public health exercise guidelines (150 minutes of moderate intensity activity per week) also reported better HRQoL [27, 31]. This relation held after controlling for age, gender, employment status, time since diagnosis and co-morbid conditions. Although patients in better health may be able to exercise more, this evidence suggests that advice to take as much exercise as is feasible is potentially valuable.

The relation between psychological variables and HRQoL was assessed in only two studies [15, 24]. Associations between psychological variables and HRQoL might suggest ways to improve guidelines for appropriate referral to psychological services. Appropriate treatment for psychological issues would be likely to facilitate survivors' attainment of the best HRQoL possible. However, in order to facilitate $\underline{\text { this, }}$ psychological issues should be assessed at follow-up. This is particularly important as psychological late effects of treatment are often not documented in medical notes [42] and thus may not be addressed by clinicians.

A number of limitations with current methodology can be identified. Only nine of the studies utilised research designs which were longitudinal or case-control. Longitudinal studies are essential to understand changes in HRQoL over time. Casecontrol studies facilitate judgement about whether HRQoL is really compromised relative to age-matched controls from the general population, and may provide greater accuracy than population norms.

More detailed description is required regarding sample demographics. First, results were not analysed by gender although three studies [18-19, 30] suggested gender differences in HRQoL. Identification of gender differences may aid clinicians in deciding what aspects of HRQoL to assess in patients, and facilitate identification 


\begin{abstract}
of correlates of HRQoL. Second, as a minimum, information is needed on socioeconomic status (assessed by more than one method where possible) and marital status. Third, studies should differentiate between survivors younger than 45 and older patients, as younger patients may have qualitatively different concerns [43].
\end{abstract}

More detailed reporting of descriptive statistics is also required. Many studies failed to report means and standard deviations. These enable comparison between studies, and are necessary for calculating effect sizes in meta-analysis [44]. Particularly where research is based on small samples from specific treatment centres, meta-analyses may be the only way to obtain information based on larger samples, and thus identify common trends across regions and cultures. They also enable assessment of individual predictors of HRQoL such as personality or demographic factors.

Serious attention should be paid to creating well-designed studies that include matched controls, and using measures that assess the full range of problems experienced by lymphoma survivors, including disease-specific modules where possible. Also, analyses should be carried out by gender in order to further understanding of demographic, medical and psychosocial correlates of HRQoL in survivors of lymphoma. This would enable clinicians to provide patients with better advice about the late effects of their disease, and suggest ways in which these effects may be prevented or mitigated.

Due to the methodological issues underlying research into HRQoL following lymphoma, only limited conclusions can be drawn. However, this review has clearly identified pathways and recommended standards for future research. In conclusion, we note the progress made in treatment of lymphomas, as demonstrated in the increasing numbers of survivors. Comparable progress is now needed to determine the range, severity and prevalence of untoward consequences of lymphoma and its treatment, and how to mitigate those consequences.

\title{
ACKNOWLEDGMENTS
}

This research was made possible by grant C481/A8141 awarded by Cancer Research UK to C Eiser and A Pacey. 


\section{References}

1. Boyle P, Levin B. World Cancer Report 2008. Lyon, France: IARC Press; 2009.

2. Office for National Statistics. One- and five-year survival (\%) for adult patients diagnosed during 1998-2001, 21 common cancers, by sex and age, England. 2005; http://www.statistics.gov.uk/StatBase/Product.asp?vlnk=14007

3. Office for National Statistics. Cancer statistics registrations: registrations of cancer diagnosed in 2006, England. 2009;

http://www.statistics.gov.uk/statbase/Product.asp?vlnk=8843

4. Ng AK, Mauch PM. Late effects of Hodgkin's Disease and its treatment. Cancer Journal 2009; 15: 164-168.

5. Cella, DF (1995). Measuring quality of life in palliative care. Seminars in Oncology 1995; 22: 73-78.

6. Soni MK, Cella D. Quality of life and symptom measures in oncology: an overview. American Journal of Managed Care 2002; 8: S560-S573.

7. Eiser C, Morse R. Quality of life measures in chronic disease in childhood. Health Technology Assessment 2001; 5 (4).

8. Cronbach LJ. Coefficient alpha and the structure of tests. Psychometrika 1951; 16: 297-334.

9. Beser NG, Oz F. Quality of life in lymphoma patients. Clinical Excellence for Nurse Practitioners; 9: 153-161.

10. Ware JE, Kosinski M, Gandek B. SF-36 Health Survey: Manual and Interpretation Guide. Lincoln, RI: QualityMetric Incorporated, 2000

11. Aaronson NK, Ahmedzai S, Bergman B et al. for the European Organization for Research and Treatment of Cancer Study Group on Quality of Life. The European Organization for Research and Treatment of Cancer QLQ-C30. A quality of life instrument for use in international clinical trials in oncology. Journal of the National Cancer Institute 1993; 85: 365-376.

12. Cella D. The Functional Assessment of Cancer Therapy-Anemia (FACT-An) Scale: A new tool for the assessment of outcomes in cancer anemia and fatigue. Seminars in Hematology 1997; 34: 13-19. 
13. Ganz PA, Schag CA, Lee JJ, et al. The CARES: A generic measure of healthrelated quality of life for patients with cancer. Quality of Life Research 1992; 1: 1929.

14. Ferrell BR, Dow KH, Grant M. Measurement of the quality of life in cancer survivors. Quality of Life Research 1995; 4: 523-531.

15. Geffen DB, Blaustein A, Amir M, Cohen Y. Post-traumatic stress disorder and quality of life in long-term survivors of Hodgkin's Disease and Non-Hodgkin's Lymphoma in Israel. Leukemia and Lymphoma 2003; 44: 1925-1929.

16. Gil-Fernandez JJ, Ramos C, Tamayo AT, et al. Quality of life and psychological well-being in Spanish long-term survivors of Hodgkin's disease: results of a controlled pilot study. Annals of Hematology 2003; 82: 14-18.

17. Hjermstad MJ, Oldervoll L, Fossa SD, Holte H, Jacobsen AB, Loge JH. Quality of life in long-term Hodgkin's disease survivors with chronic fatigue. European Journal of Cancer 2006; 42: 327-333.

18. Joly F, Henry-Amar M, Arveux P, et al. Late psychosocial sequelae in Hodgkin's Disease survivors: a French population-based case-control study. Journal of Clinical Oncology 1996; 14: 2444-2453.

19. Loge JH, Abrahamsen AF, Ekeberg O, Kaasa S. Reduced health-related quality of life among Hodgkin's disease survivors: A comparative study with general population norms. Annals of Oncology 1999; 10: 71-77.

20. Mols F, Vingerhoets AJJM, Coebergh JW, et al. Better quality of life among 1015 year survivors of Hodgkin's lymphoma compared to 5-9 year survivors: A population-based study. European Journal of Cancer 2006; 42: 2794-2801.

21. Mols F, Coebergh JWW, van de Poll-Franse LV. Health-related quality of life and health care utilisation among older long-term cancer survivors: A population-based study. European Journal of Cancer 2007; 43: 2211-2221.

22. Mols F, Aaronson NK, Vingerhoets AJJM, et al. Quality of life among long-term Non-Hodgkin Lymphoma survivors: A population-based study. Cancer 2007; 109: 1659-1667.

23. van Tulder MW, Aaronson NK, Bruning PF. The quality of life of long-term survivors of Hodgkin's disease. Annals of Oncology 1994; 5: 153-158.

24. Wettergren L, Bjorkholm M, Axdorph U, Langius-Eklof A. Determinants of health-related quality of life in long-term survivors of Hodgkin's lymphoma. Quality of Life Research 2004; 13: 1369-1379. 
25. Ahles TA, Saykin AJ, Furstenberg CT, et al. Quality of life of long-term survivors of breast cancer and lymphoma treated with standard-dose chemotherapy or local therapy. Journal of Clinical Oncology 2005; 23: 43994405.

26. Bellizzi KM, Farmer Miller M, Arora NK, Rowland JH. Positive and negative life changes experienced by survivors of Non-Hodgkin's Lymphoma. Annals of Behavioral Medicine 2007; 34: 188-199.

27. Bellizzi KM, Rowland JH, Arora NK, Hamilton AS, Farmer Miller M, Aziz NM. Physical activity and quality of life in adult survivors of Non-Hodgkin's Lymphoma. Journal of Clinical Oncology 2009; 27: 960-966.

28. Ganz PA, Moinpour CM, Pauler DK, et al. Health status and quality of life in patients with early-stage Hodgkin's disease treated on Southwest Oncology Group Study 9133. Journal of Clinical Oncology 2003; 21: 3512-3519.

29. Greil R, Holzner B, Kemmler G, et al. Retrospective assessment of quality of life and treatment outcome in patients with Hodgkin's Disease from 1969 to 1994. European Journal of Cancer 1999; 35: 698-706.

30. Norum J, Wist EA. Quality of life in survivors of Hodgkin's disease. Quality of Life Research 1996; 5: 367-374.

31. Vallance JKH, Courneya KS, Jones LW, Reiman T. Differences in quality of life between Non-Hogkin's Lymphoma survivors meeting and not meeting public health exercise guidelines. Psycho-Oncology 2005; 14: 979-991.

32. Zebrack BJ, Yi J, Petersen L, Ganz PA. The impact of cancer and quality of life for long-term survivors. Psycho-Oncology 2008; 17: 891-900.

33. Antonovsky, A. Unravelling the mystery of health: How people manage stress and stay well. San Francisco: Jossey-Bass, 1987.

34. Gotay CC, Muraoka MY. Quality of life in long-term survivors of adult-onset cancers. Journal of the National Cancer Institute 1998; 90: 656-667.

35. Avis NE, Smith, KW, McGraw S, Smith RG, Petronis VM, Carver CS. Assessing Quality of Life in Adult Cancer Survivors (QLACS). Quality of Life Research 2005; 14: 1007-1023.

36. Eiser C, Jenney M. Measuring quality of life. Archives of Disease in Childhood 2007; 92: 348-350.

37. Krahn M, Bremner KE, Tomlinson G, Ritvo P, Irvine J, Naglie G. Responsiveness of disease-specific and generic utility instruments in prostate cancer patients. 
Quality of Life Research 2007; 16: 509-522.

38. Pearce NJM, Sanson-Fisher R, Campbell HS. Measuring quality of life in cancer survivors: a methodological review of existing scales. Psycho-Oncology 2008; 17: 629-640.

39. Ruffer JU, Flechtner H, Tralls P, et al. Fatigue in long-term survivors of Hodgkin's lymphoma, a report from the German Hodgkin Lymphoma Study Group (GHSG). European Journal of Cancer 2003; 39: 2179-2186.

40. Smets EMA, Garssen B, Schusteruitterhoeve ALJ, Dehaes JCJM. Fatigue in cancer patients. British Journal of Cancer 1993; 68: 220-224.

41. Schnohr C, Hojbjerre L, Riegels M, et al. Does educational level influence the effects of smoking, alcohol, physical activity and obesity on mortality? A prospective population study. Scandinavian Journal of Public Health 2004; 32: 250-256.

42. Eiser C, Taylor N, Absolom K, Michel G. Under-diagnosis of morbidity in survivors of childhood cancer: Implications for follow-up care. [abstract]. Psychology \& Health. 2009; 24 S1: 32.

43. Eiser C, Penn A, Katz E, Barr R. Psychosocial issues and quality of life. Seminars in Oncology 2009; 36: 275-280.

44. Glass G. Integrating findings: The meta-analysis of research. Review of Research in Education, 1977; 5: 351-379. 


\section{Page 17 of 25}

Leukemia and Lymphoma

Table I: Description of measures used

\begin{tabular}{|c|c|c|c|c|}
\hline Scale & Subscales & $\underline{\text { Reliability }}$ & $\underline{\text { Validity }}$ & $\begin{array}{l}\text { Type of } \\
\text { measure }\end{array}$ \\
\hline $\begin{array}{l}\text { SF-36 [8] } \\
\text { (Ware et al., } \\
\text { 2002) }\end{array}$ & $\begin{array}{l}\text { Physical component summary (physical functioning, } \\
\text { role limitations due to physical problems, bodily pain, } \\
\text { general health) } \\
\text { Mental component summary (social functioning, role } \\
\text { limitations due to emotional problems, vitality, mental } \\
\text { health) }\end{array}$ & $\begin{array}{l}\text { Test-retest; } \\
\underline{\alpha>0.70}\end{array}$ & $\begin{array}{l}\text { Correlates with observable physical } \\
\underline{\text { outcomes }}\end{array}$ & Generic \\
\hline $\begin{array}{l}\text { EORTC QLQ- } \\
\text { C30 [9] } \\
\text { (Aaronson et } \\
\text { al., 1993) }\end{array}$ & $\begin{array}{l}\text { Physical, Role, Emotional, Cognitive and Social } \\
\text { functioning, Global health status, Physical symptoms } \\
\text { (fatigue, nausea and vomiting, pain, dyspnoea, sleep } \\
\text { disturbance, appetite loss, constipation, diarrhoea) }\end{array}$ & $\begin{array}{l}\text { Test-retest; } \\
\alpha>0.70\end{array}$ & $\begin{array}{l}\text { Distinguishes patients with different } \\
\text { performance status }\end{array}$ & $\begin{array}{l}\text { Cancer- } \\
\text { specific; } \\
\text { appropriate } \\
\text { during } \\
\text { treatment }\end{array}$ \\
\hline $\begin{array}{l}\text { FACT-An [10] } \\
\text { (Cella et al., } \\
\text { 1997) }\end{array}$ & $\begin{array}{l}\text { Physical, Functional, Emotional, Social well-being, } \\
\text { Anaemia symptoms }\end{array}$ & $\begin{array}{l}\text { Test-retest; } \\
\underline{\alpha>0.70}\end{array}$ & $\begin{array}{l}\text { Discriminates based on medical } \\
\text { variables; correlated with appropriate } \\
\text { scales }\end{array}$ & $\begin{array}{l}\text { Cancer- } \\
\text { specific; } \\
\text { appropriate } \\
\text { during } \\
\text { treatment }\end{array}$ \\
\hline
\end{tabular}

17 


\begin{tabular}{|c|c|c|c|c|}
\hline $\begin{array}{l}\text { CARES } \underline{(\text { Ganz }} \\
\text { et al., 1992) }\end{array}$ & $\begin{array}{l}\text { Physical, psychosocial, marital, medical interaction, } \\
\text { sexual }\end{array}$ & $\begin{array}{l}\text { Test-retest; } \\
\underline{\alpha>0.70}\end{array}$ & $\begin{array}{l}\text { Comprehensive; correlates with } \\
\text { appropriate scales }\end{array}$ & $\begin{array}{l}\text { Cancer- } \\
\text { specifici } \\
\text { appropriate } \\
\text { during } \\
\text { treatment }\end{array}$ \\
\hline $\begin{array}{l}\text { QoL-CS [11] } \\
\text { (Ferrell et al., } \\
\text { 1995) }\end{array}$ & Physical, Psychological, Social, Spiritual well-being & $\begin{array}{l}\underline{\text { Test-retest; }} \\
\underline{\alpha>0.70}\end{array}$ & $\begin{array}{l}\text { Correlates with appropriate scales, } \\
\text { discriminates based on demographic } \\
\text { and medical variables }\end{array}$ & $\begin{array}{l}\text { Cancer- } \\
\text { specific: } \\
\text { survivors }\end{array}$ \\
\hline
\end{tabular}

18 
Table II: Correlates of quality of life: studies with comparison group

\begin{tabular}{|c|c|c|c|c|c|c|c|c|}
\hline $\begin{array}{l}\text { Study and } \\
\text { country of origin }\end{array}$ & Aims & $\begin{array}{l}\text { Sample } \\
\text { (response } \\
\text { rate) }\end{array}$ & $\begin{array}{l}\text { Age } \\
\underline{\text { (Mean, }} \\
\underline{\text { (range) }} \\
{[\mathrm{SD}]}\end{array}$ & $\begin{array}{l}\text { Time since } \\
\text { diagnosis } \\
\underline{\text { Mean, }} \\
\underline{\text { range })} \\
\text { (years) }\end{array}$ & Treatment (n) & $\begin{array}{l}\text { Comparison } \\
\text { Group (n) }\end{array}$ & Measures & Findings \\
\hline $\begin{array}{l}\text { 1. Geffen et al. } \\
\text { (2003) [12] } \\
\text { Israel }\end{array}$ & $\begin{array}{l}\text { 1. Assess frequency of } \\
\text { PTSD and PTSD } \\
\text { symptoms relative to } \\
\text { controls } \\
\text { 2. Explore relation } \\
\text { between PTSD and } \\
\text { HRQoL }\end{array}$ & $\begin{array}{l}44(96 \%): \\
36 \mathrm{HL}, \\
8 \mathrm{NHL} \\
(46 \% \text { men })\end{array}$ & $51(27-80)$ & $\begin{array}{l}7.9(2-16) \text { all } \\
2 \text { yrs }+ \text { since } \\
\text { treatment }\end{array}$ & $\begin{array}{l}\text { RT: } 6 \\
\text { CT: } 24 \\
\text { Both: } 14\end{array}$ & $\begin{array}{l}4 \text { matched } \\
\text { controls (sex, } \\
\text { marital status, } \\
\text { education, age) } \\
\text { experienced } \\
\text { traumatic event }\end{array}$ & SF-36 & $\begin{array}{l}\text { 1) Lower physical HRQoL than } \\
\text { controls, even after controlling for } \\
\text { PTSD symptoms } \\
\text { 2) Higher intensity PTSD a/w lower } \\
\text { HRQoL }\end{array}$ \\
\hline $\begin{array}{l}\text { 2. Gil-Fernandez } \\
\text { et al. (2003) [13] } \\
\text { Spain }\end{array}$ & $\begin{array}{l}\text { 1. Assess HRQoL and } \\
\text { psychological well-being } \\
\text { of Spanish survivors }\end{array}$ & $\begin{array}{l}46(68.6 \%) \\
32 \text { men }\end{array}$ & $43(15-80)$ & $\begin{array}{l}7.6(0.8- \\
22.1)\end{array}$ & $\begin{array}{l}\text { RT: } 7 \\
\text { CT: } 10 \\
\text { Both: } 29\end{array}$ & $\begin{array}{l}46 \mathrm{GP} \text {, matched } \\
\text { for age, sex, } \\
\text { social status }\end{array}$ & $\begin{array}{l}\text { EORTC } \\
\text { QLQ-C30 }\end{array}$ & $\begin{array}{l}\text { 1) Worse physical function, family } \\
\text { relationships, more dyspnoea and } \\
\text { economic difficulties than general } \\
\text { population } \\
\text { 2) Women worse physical HRQoL } \\
\text { than men }\end{array}$ \\
\hline $\begin{array}{l}\text { 3. Hjermstad et } \\
\text { al. (2006) [14] } \\
\text { Norway }\end{array}$ & $\begin{array}{l}\text { 1. Assess } \mathrm{HRQoL} \text { in } \\
\text { survivors with chronic } \\
\text { fatigue }\end{array}$ & $\begin{array}{l}475 \mathrm{HL} \\
(80 \%) \\
56 \% \text { men }\end{array}$ & $46 \underline{(21-74)}$ & $\frac{195(53-431)}{\underline{\text { months }}}$ & $\mathrm{RT} / \mathrm{CT}$ & $\begin{array}{l}\text { GP (2141), } \\
\text { same age range } \\
\text { as patients, } \\
\text { adjusted for sex, } \\
\text { educational } \\
\text { level }\end{array}$ & SF-36 & $\begin{array}{l}\text { 1) Lower physical HRQoL than } \\
\text { general population, chronic fatigue } \\
3 x \text { higher }\end{array}$ \\
\hline
\end{tabular}

19 


\begin{tabular}{|c|c|c|c|c|c|c|c|c|}
\hline $\begin{array}{l}\text { 4. Joly et al. } \\
\text { (1996) [15] } \\
\text { France }\end{array}$ & $\begin{array}{l}\text { 1. Determine type and } \\
\text { frequency of } \\
\text { psychosocial problems in } \\
\text { French long-term } \\
\text { survivors relative to } \\
\text { controls }\end{array}$ & $\begin{array}{l}93 \mathrm{HL} \\
(91 \%) \\
\text { Numbers of } \\
\text { each gender } \\
\text { not reported } \\
\text { separately } \\
\text { for patients } \\
\text { and controls }\end{array}$ & $42(23-85)$ & $10(4-17)$ & $\begin{array}{l}\text { RT: } 34 \% \\
\text { CT: } 4 \% \\
\text { Both: } 62 \% \\
\text { MOPP: } 74 \% \\
\text { ABVD: } 16 \% \\
\text { Both: } 10 \%\end{array}$ & $\begin{array}{l}186 \mathrm{GP}, \\
\text { matched for age, } \\
\text { sex, city of } \\
\text { residence }\end{array}$ & $\begin{array}{l}\text { EORTC } \\
\text { QLQ-C30 }\end{array}$ & $\begin{array}{l}\text { 1) Lower physical, role cognitive } \\
\text { and social functioning, more } \\
\text { dyspnoea, fatigue than general } \\
\text { population } \\
\text { 2) Men better role functioning than } \\
\text { women } \\
\text { 3) Lower educational level: worse } \\
\text { physical, role functioning, more } \\
\text { dyspnoea } \\
\text { 4) Medical complications: more } \\
\text { dyspnoea, lower physical, role and } \\
\text { cognitive function }\end{array}$ \\
\hline $\begin{array}{l}\text { 5. Loge et al. } \\
\text { (1999) [16] } \\
\text { Norway }\end{array}$ & $\begin{array}{l}\text { 1. Compare HRQoL with } \\
\text { norms from general } \\
\text { population } \\
\text { 2. Determine disease or } \\
\text { treatment factors } \\
\text { affecting HRQoL }\end{array}$ & $\begin{array}{l}459 \mathrm{HL} \\
(82 \%) \\
56 \% \text { men }\end{array}$ & 44 [11.8] & $12.2(\underline{3-23})$ & $\begin{array}{l}\text { RT: } 174 \\
\text { CT: } 66 \\
\text { Both: } 217 \\
\text { RT: } 76 \% \\
\text { mantle field } \\
\text { LVPP: } 54 \% \\
\text { ABOD: } 46 \%\end{array}$ & As for 3 & SF-36 & $\begin{array}{l}\text { 1) ) Lower vitality, general health, } \\
\text { physical functioning, role physical, } \\
\text { social functioning than general } \\
\text { population } \\
\text { 2) Men better role physical, } \\
\text { physical functioning, role emotional } \\
\text { than women } \\
\text { 3) More education: better physical } \\
\text { HRQoL }\end{array}$ \\
\hline $\begin{array}{l}\text { 6. Mols et al.* } \\
\text { (2006) [17] } \\
\text { Netherlands }\end{array}$ & $\begin{array}{l}\text { 1. Examine differences } \\
\text { between survivors and } \\
\text { age-matched controls } \\
\text { 2. Compare HRQoL of } \\
\text { 5-9 years and 10-15 } \\
\text { years survivors }\end{array}$ & $\begin{array}{l}132 \mathrm{NHL} \\
(80 \%) \\
\text { Gender not } \\
\text { reported }\end{array}$ & $\begin{array}{l}20-34 ; \\
35-49 ; 50+\end{array}$ & $\begin{array}{l}48: \\
5-9 \text { yrs } \\
68: \\
10-15 \text { yrs }\end{array}$ & $\begin{array}{l}\text { RT: } 25 \\
\text { CT: } 38 \\
\text { Both: } 66\end{array}$ & $\begin{array}{l}\text { Age-matched GP } \\
(1771)\end{array}$ & $\begin{array}{l}\text { SF-36; } \\
\text { QOL-CS }\end{array}$ & $\begin{array}{l}\text { 1) } 5-9 \text { yrs: lower general health, } \\
\text { social functioning, mental hea Deleted: If } \\
\text { than controls } \\
\text { 2) } 10-15 \mathrm{yrs} \text { : lower general health } \\
\text { than controls, but higher physical } \\
\text { functioning } \\
\text { 3) } 10-15 \text { years: higher HRQoL } \\
\text { than 5-9yrs survivors: vitality, } \\
\text { social functioning, role emotional, } \\
\text { mental health }\end{array}$ \\
\hline
\end{tabular}




\begin{tabular}{|c|c|c|c|c|c|c|c|c|}
\hline $\begin{array}{l}\text { 7. Mols et al. } \\
(2007 a) *[18] \\
\text { Netherlands }\end{array}$ & $\begin{array}{l}\text { 1. Compare HRQoL with } \\
\text { general population } \\
\text { 2. Compare survivors } \\
\text { over and under } 70\end{array}$ & $\begin{array}{l}155 \mathrm{NHL} \\
\text { survivors } \\
(80 \% \text { of full } \\
\text { sample) } \\
54 \% \text { male }\end{array}$ & 70 & $\begin{array}{l}\text { Not reported } \\
\text { by disease }\end{array}$ & $\begin{array}{l}\text { Surgery: } 22 \\
\text { RT: } 85 \\
\text { CT: } 115 \\
\text { Surveillance: } \\
12 \\
\text { Combinations } \\
\text { not reported }\end{array}$ & As 6 & SF-36 & $\begin{array}{l}\text { 1) Younger: lower vitality, general } \\
\text { health, but less pain } \\
\text { 2) Co-morbidity: worse social } \\
\text { function, physical health, role } \\
\text { emotional, } \\
\text { 3) More education: better physical } \\
\text { function } \\
\text { 4) Employed: better role physical, } \\
\text { role emotional, general health }\end{array}$ \\
\hline $\begin{array}{l}\text { 8. Mols et al. } \\
(2007 b)^{*}[19] \\
\text { Netherlands }\end{array}$ & $\begin{array}{l}\text { 1. Investigate association } \\
\text { of demographic and } \\
\text { clinical factors with } \\
\text { HRQoL } \\
\text { 2. Compare HRQoL to } \\
\text { general population }\end{array}$ & $\begin{array}{l}221 \mathrm{NHL} \\
\text { survivors } \\
(82 \%) \\
51 \% \text { male }\end{array}$ & 55.3 & $\begin{array}{l}5-9 \text { yrs: } 145 \\
\text { months } \\
10-15 y r s: 76 \\
\text { months }\end{array}$ & $\begin{array}{l}\text { RT: } 33 \\
\text { CT: } 82 \\
\text { Both: } 58 \\
\text { Also surgery: } \\
28 \\
\text { Wait: } 20\end{array}$ & As 6 & $\begin{array}{l}\text { SF-36; } \\
\text { QOL-CS }\end{array}$ & $\begin{array}{l}\text { 1) Chemo: lower social and } \\
\text { psychological well-being } \\
\text { 2) Older age: lower physical } \\
\text { functioning } \\
\text { 3) Co-morbid conditions: poorer } \\
\text { physical functioning, more pain } \\
\text { 4) Employed: better vitality, mental } \\
\text { health } \\
\text { 5) Longer since diagnosis: better } \\
\text { social well-being (QoL-CS) }\end{array}$ \\
\hline $\begin{array}{l}\text { 10. Wettergren et } \\
\text { al. (2004) [21] } \\
\text { Sweden }\end{array}$ & $\begin{array}{l}\text { 1. Evaluate HRQoL in } \\
\text { long-term HL survivors } \\
\text { 2. Identify determinants } \\
\text { of HRQoL }\end{array}$ & $\begin{array}{l}121(62 \%) \\
55 \% \text { male }\end{array}$ & $47(23-75)$ & $13(6-24)$ & $\begin{array}{l}\text { MOPP: } 14 \\
\text { RT: } 55 \\
\text { CT: } 28 \\
\text { Both: } 17\end{array}$ & $\begin{array}{l}236 \text { GP (stratified by } \\
\text { age and sex) }\end{array}$ & SF-12 & $\begin{array}{l}\text { 1) Poorer physical health than } \\
\text { controls } \\
\text { 2) More advanced disease: more } \\
\text { disease-related problems } \\
\text { 3 Lower sense of coherence: worse } \\
\text { HRQoL }\end{array}$ \\
\hline
\end{tabular}

Glossary: SF-36: Short Form-36 health survey; RT - Radiotherapy; CT - chemotherapy; EORTC QLQ-C30: European Organization for Research and Treatment of Cancer

Quality of Life Questionnaire; GP - general population; QOL-CS: Quality of Life-Cancer Survivors; MOPP - Mechlorethamine, vincristine, procarbazine, prednisone;

ABVD - Doxorubicin, bleomycin, vinblastine, dacarbazine; LVPP - Chlorambucil, vinblastine, procarbazine, prednisone; ABOD - doxorubicin, bleomycin, vincristine,

dacarbazine

* These studies are drawn from the same population 
Table III: Correlates of quality of life: studies without comparison group

\begin{tabular}{|c|c|c|c|c|c|c|c|}
\hline Study & Aims & $\begin{array}{l}\text { Sample } \\
\text { (response } \\
\text { rate) }\end{array}$ & $\begin{array}{l}\text { Age } \\
\text { (Mean, } \\
\text { (range) [SD] }\end{array}$ & $\begin{array}{l}\text { Time since } \\
\text { diagnosis } \\
\text { (years) } \\
\text { (Mean, } \\
\text { (range) [SD] }\end{array}$ & Treatment & Measures & Findings \\
\hline $\begin{array}{l}\text { 1. Ahles et al. } \\
\text { (2005) [22] } \\
\text { USA } \\
\text { | }\end{array}$ & $\begin{array}{l}\text { 1. Compare QoL of long-term } \\
\text { survivors of lymphoma treated with } \\
\text { chemotherapy or surgery }\end{array}$ & $\begin{array}{l}103(76 \% \\
\text { overall }) \\
\text { Chemo: } 45 \% \\
\text { male } \\
\text { Surgery: } \\
48.7 \% \text { male }\end{array}$ & $\begin{array}{l}\text { Chemo: } \\
55.8[13.5] \\
\text { Surgery: } \\
50.4(12.8)\end{array}$ & $10.0[5.3]$ & $\begin{array}{l}\text { CT: } 66 \\
\text { Surgery: } 37\end{array}$ & QOL-CS & $\begin{array}{l}\text { 1) Chemo: worse social and physical QoL- } \\
\text { more fatigue, aches and pains, worse overall } \\
\text { health } \\
\text { 2) Chemo: more fertility concerns, greater } \\
\text { interference of cancer and treatment on } \\
\text { employment }\end{array}$ \\
\hline $\begin{array}{l}\text { 2. Bellizzi et al. } \\
\text { (2007)* [23] } \\
\text { USA }\end{array}$ & $\begin{array}{l}\text { 1. Describe association between } \\
\text { demographic, disease-related and } \\
\text { psychosocial factors, and positive } \\
\text { and negative life change }\end{array}$ & $\begin{array}{l}\text { NHL } 308 \\
(72.5 \%) \\
51.3 \% \text { male }\end{array}$ & $60(23-85)$ & $3.5[0.1]$ & CT: $94.2 \%$ & SF-36 & $\begin{array}{l}\text { 1) Increase in negative life change: decline } \\
\text { in physical and mental functioning }\end{array}$ \\
\hline $\begin{array}{l}\text { 3. Bellizzi et al. } \\
\text { (2009)* [24] } \\
\text { USA }\end{array}$ & $\begin{array}{l}\text { 1. Examine demographic, disease- } \\
\text { related and cognitive factors a/w } \\
\text { physical activity in NHL survivors } \\
\text { 2. Explore relation between } \\
\text { physical activity and HRQoL }\end{array}$ & $\begin{array}{l}\text { NHL } 319 \\
(72.5 \%) \\
51.3 \% \text { male }\end{array}$ & $59.8(14.8)$ & $\begin{array}{l}2-5.9(3 \\
\text { groups })\end{array}$ & $\begin{array}{l}\text { CT: } 156 \\
\text { CT+ RT: } 108 \\
\text { Transplant: } 34\end{array}$ & SF-36 & $\begin{array}{l}\text { 1) Met guidelines for exercise or some } \\
\text { activity: better mental and physical health } \\
\text { than if sedentary, significant dose-response } \\
\text { pattern } \\
\text { 2) Similar results - anxiety and depression } \\
\text { 3) } 25 \% 1 \text { SD below norm - mental health, } \\
\text { 1.5 SDs below norm - physical health }\end{array}$ \\
\hline $\begin{array}{l}\text { 4. Ganz et al. } \\
\text { (2003) [25] } \\
\text { USA }\end{array}$ & $\begin{array}{l}\text { 1. Examine outcomes during first } \\
\text { two years after assignment to STLI } \\
\text { or CMT in SWOG trial }\end{array}$ & $\begin{array}{l}\text { Baseline } 237 \\
(97 \%) \\
60 \% \text { male } \\
2 \text { yrs: } 160 \\
(70 \%)\end{array}$ & $\begin{array}{l}\text { Radiation: } \\
31.4(17-85) \\
\text { Combined: } \\
33.7 \text { (17-71) }\end{array}$ & $\begin{array}{l}\text { Recruited at } \\
\text { diagnosis, } 2 \\
\text { yr follow-up }\end{array}$ & $\begin{array}{l}\text { At } 2 \mathrm{yrs} \\
\text { STLI: } 78 \\
\text { STLI+CMT: } 82\end{array}$ & $\begin{array}{l}\text { CARES- } \\
\text { SF; SF-36 } \\
\text { vitality, } \\
\text { general } \\
\text { health }\end{array}$ & $\begin{array}{l}\text { 1) No differences between radiation and } \\
\text { combination therapy at } 2 \text { years in terms of } \\
\text { effects on HRQoL, vitality } \\
\text { 2) Physical, psychosocial, sexual, marital } \\
\text { and medical interaction returned to baseline } \\
\text { 2) General health worse at } 2 \text { years }\end{array}$ \\
\hline $\begin{array}{l}\text { 5. Greil et al. } \\
\text { (1999) [26] } \\
\text { Austria }\end{array}$ & $\begin{array}{l}\text { 1. Assess QoL in HD survivors } \\
\text { 2. Investigate impact of different } \\
\text { treatment modalities on QoL }\end{array}$ & $\begin{array}{l}\text { HD } 126 \\
(64.9 \%) \\
99 / 225\end{array}$ & $\begin{array}{l}36.9 \\
(6-89) \text { at } \\
\text { diagnosis }\end{array}$ & $\begin{array}{l}10.5(\underline{0.9-} \\
\underline{34.0})\end{array}$ & $\begin{array}{l}\text { CT: } 63 \\
\text { RT: } 70 \\
\text { Both: } 92\end{array}$ & $\begin{array}{l}\text { EORTC } \\
\text { QLQ-C30 }\end{array}$ & $\begin{array}{l}\text { 1) More deficits in physical function, } \\
\text { dyspnoea, pain, \& fatigue if combined } \\
\text { modality therapy }\end{array}$ \\
\hline
\end{tabular}




\begin{tabular}{|c|c|c|c|c|c|c|c|}
\hline $\begin{array}{l}\text { 6. Norum \& Wist } \\
\text { (1996) [27] } \\
\text { Norway }\end{array}$ & $\begin{array}{l}\text { 1. Document QoL in HLsurvivors } \\
\text { 2. Determine whether mantle field } \\
\text { irradiation causes reduced QoL } \\
\text { 3. Determine whether QoL differs } \\
\text { by gender }\end{array}$ & $\begin{array}{l}\text { HL } 42(86 \%) \\
24 \text { male }\end{array}$ & Not reported & Not reported & $\begin{array}{l}\text { RT: } 10 \\
\text { CT: } 16 \\
\text { Both: } 16\end{array}$ & $\begin{array}{l}\text { EORTC } \\
\text { QLQ C-30 }\end{array}$ & $\begin{array}{l}\text { 1) Mantle field radiation: dyspnoea } \\
\text { 2) Males greater fatigue, lower HRQoL } \\
\text { 3) Sleep disturbance: fatigue, pain, financial } \\
\text { difficulties, dyspnoea, worse HRQoL } \\
\text { 4) Physical condition/ medical treatment } \\
\text { caused financial difficulties in } 45 \%\end{array}$ \\
\hline $\begin{array}{l}\text { 7. Vallance et al. } \\
\text { (2005) [28] } \\
\text { Canada }\end{array}$ & $\begin{array}{l}\text { 1. Examine HRQoL differences } \\
\text { between NHL survivors meeting } \\
\text { and not meeting exercise guidelines }\end{array}$ & $\begin{array}{l}\text { NHL } 438 \\
(62 \%) \\
51.6 \% \text { male }\end{array}$ & $61.1[13.1]$ & $\begin{array}{l}62 \text { [25.3] } \\
\text { (months) }\end{array}$ & $\begin{array}{l}\text { CT: } 64.6 \% \\
\text { CT+RT: } 15.5 \% \\
\text { Wait: } 17.1 \%\end{array}$ & FACT-An & $\begin{array}{l}\text { 1) Meeting exercise guidelines ( } 150 \\
\text { minutes/ week): better physical, emotional } \\
\text { and functional HRQoL }\end{array}$ \\
\hline $\begin{array}{l}\text { 8. Zebrack et al. } \\
\text { (2008) [29] } \\
\text { USA }\end{array}$ & $\begin{array}{l}\text { 1. Examine relation between } \\
\text { perceptions of impact of cancer and } \\
\text { HRQoL, across cancers, after } \\
\text { controlling for medical and socio- } \\
\text { demographic factors }\end{array}$ & $\begin{array}{l}193(33 \%) \\
49 \mathrm{HL} / \mathrm{NHL} \\
56 \% \text { male } \\
\text { (overall) }\end{array}$ & $\begin{array}{l}61.5 \\
{[14.3] \text { Whole }} \\
\text { sample }\end{array}$ & 7.7 [1.9] & Not reported & $\begin{array}{l}\text { SF-36 } \\
\text { QOL-CS }\end{array}$ & $\begin{array}{l}\text { 1) Fewer co-morbidities: better physical } \\
\text { health, HRQoL } \\
\text { 2) Younger age: better physical health, but } \\
\text { worse mental health, overall HRQoL } \\
\text { 3) Employed: better physical health }\end{array}$ \\
\hline
\end{tabular}

Glossary: QOL-CS - Quality of Life - Cancer Survivors; CT - chemotherapy; RT - radiotherapy; SF-36 - Short Form 36 health survey; STLI - subtotal lymphoid irradiation; CMT - combined modality therapy; CARES-SF - Cancer Rehabilitation Evaluation System - Short Form; EORTC QLQ-C30 : European Organization for Research and Treatment of Cancer Quality of Life Questionnaire; FACT-An - Functional Assessment of Cancer Therapy - Anaemia

*These studies are drawn from the same population 
Figure 1: Search process

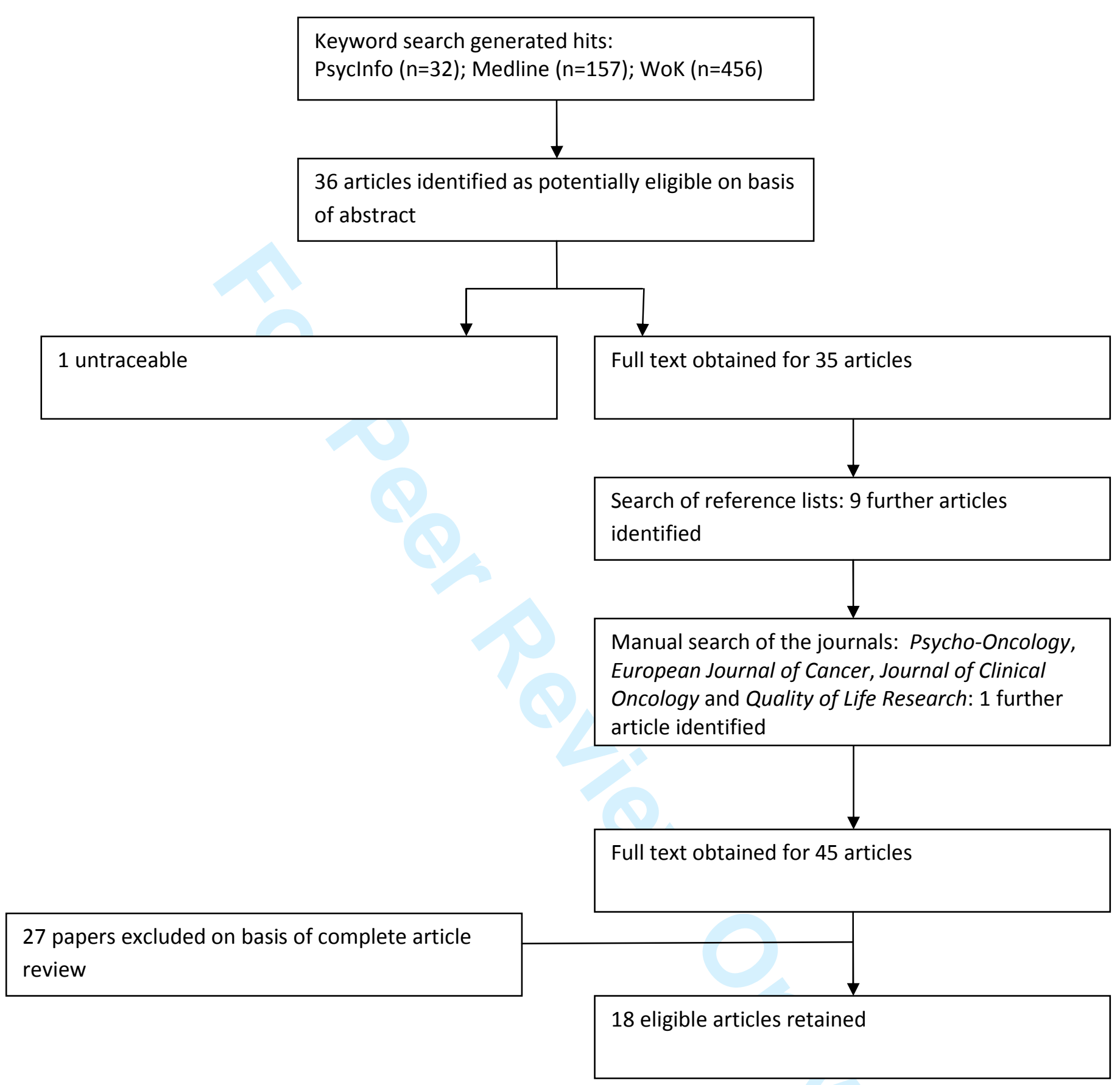


Figure II: Summary of Findings and Recommendations for Future Research

\section{Measures}

- Measures designed for use during treatment used on longterm cancer survivors

\section{Recommendation:}

- Studies should utilise a survivor-specific and a generic measure of HRQoL

\section{Correlates of HRQoL}

- Lymphoma survivors have poor physical HRQoL, but mental HRQoL equivalent to general population on average

- Correlates of better physical HRQoL: younger age, higher educational level, following exercise guidelines

- Insufficient evidence to determine:

1) Effects of treatment on HRQoL

2) Relation between psychological factors and HRQoL

\section{Recommendations for future research:}

- Use of longitudinal designs

- Detailed reporting of demographics and descriptive statistics 